\title{
Review
}

\section{Endothelin in Vascular and Endocrine Systems: Biological Activities and Its Mechanisms of Action}

\author{
YoH TAKUWA \\ Department of Cardiovascular Biology, Faculty of Medicine, \\ University to Tokyo 113, Japan
}

\section{Introduction}

SINCE ITS DISCOVERY IN 1988 [1], endothelin has been the subject of intensive investigation in the fields of cardiovascular biology, endocrinology and clinical medicine. In the past five years a huge number of reports describing pleiotropic biological actions of this novel bioactive peptide have rapidly been accumulated [2-4].

Endothelin was originally isolated as a potent vasoconstrictive activity from the culture supernatant of porcine aortic endothelial cells. Immediately thereafter, endothelin was found to exert complex actions on the vascular system, i.e. direct vasoconstriction and endotheliumdependent vasodilatation [5,6]. Subsequent studies demonstrated that a wide variety of tissues outside the cardiovascular system possess high affinity specific binding sites for endothelin [7], and that endothelin induces diverse biological responses in these tissues, which include modulation of hormone release from various endocrine organs [8], regulation of the transport in the renal tubule $[9,10]$ and modulation of the central nervous activity [11]. One of the outstanding achievements in the progress of the endothelin research was the cloning of three distinct endothelin-related genes [12], which led to the discovery that mammals including human produce three members of this peptide family, endothelin-1 (the 'classical endothelin'), endothelin-2 and endothe-

This review was written as a memorial article for the Research Encouragement Prize of the Japan Endocrine Society awarded to the author on May 28th, 1992.

Correspondence to: Dr. Yoh TAKUWA, Department of Cardiovascular Biology, Faculty of Medicine, University of Tokyo, 7-3-1 Hongo, Bunkyo-ku, Tokyo 113, Japan lin-3. Binding studies using each of the radiolabeled endothelin isopeptides suggested the existence of receptor subtypes with different affinities for each isoform of the endothelin family peptides [13]. Indeed, subsequent molecular cloning of endothelin receptor cDNA identified two subtypes, i.e. a ET-1-selective $\mathrm{ET}_{\mathrm{A}}$ subtype [14] and a non-selective $\mathrm{ET}_{\mathrm{B}}$ subtype [15], which show distinct patterns of tissue specific expression. The existence of three endothelin isoforms and two subtypes of their receptors may in part underlie the diversity of biological activities of the endothelin family peptides. However, it remains to be elucidated whether the reported biological activities of endothelins, both within and outside the cardiovascular system, have physiological or pathophysiological significance, since most of them are based upon the data obtained with exogenously administered endothelin peptides. Recently discovered subtype-selective agonists [16] and antagonists [17] for endothelin receptors should serve as useful tools for addressing such questions and contribute to further understanding of the pathophysiological role of this novel peptide family.

In this article, I will briefly review the current status of knowledge concerning this novel peptide with special emphasis on its actions on the vascular and endocrine systems.

\section{Vascular Actions}

Pressor and Depressor Responses

Intravenous bolus injection of endothelin-1 causes an acute biphasic hemodynamic response in 
autonomically blocked rats: an initial transient (lasting 0.5-2 min) decrease in mean arterial pressure which is accompanied by systemic vasodilation (depressor response), followed by a remarkably sustained increase in mean arterial pressure which is accompanied by systemic vasoconstriction (pressor response) [1,5]. Intravenous administration of endothelin- 1 to experimental animals is also reported to induce moderate increases in plasma concentrations of vasoactive agonists such as adrenaline and vasopressin [8, 18]. Based upon the observations that the pressor response by endothelin- 1 is barely affected by pretreatment with the receptor antagonists for these vasoactive agonists, and that endothelin-1 provokes a potent contraction of isolated arterial strips from various vascular regions [1], the acute pressor response to endothelin- 1 infusion is considered to be mediated largely by its direct constrictive action on vascular smooth muscle. There are several exceptions reported including rat hepatic vascular bed [19], isolated canine basilar artery [20] and isolated aorta from spontaneously hypertensive rats [21], where endotheliumderived thromboxane $A_{2}$ is suggested to contribute significantly to contractions evoked by endothelins.

The endothelin-1-induced vasodilation is abolished by removal of endothelium, and is inhibited to various degrees, depending on vascular regions employed in the experiments, by cyclooxygenase inhibitors or endothelium-derived relaxing factor (EDRF) inhibitors such as methylene blue and oxyhemoglobin, indicating that the endothelin-1induced vasodilation is mediated by release of vasodepressor prostanoids and EDRF from the endothelium $[5,6]$. In the first report by Warner $e t$ al. [6] on the vasodilator effect of endothelins, it was already recognized that endothelin-3 with much less potency in vasoconstrictor activity was equipotent with endothelin-1 in inducing the vasodilator response, suggesting that endothelin receptors existent in vascular smooth muscle and the endothelium were different. In fact, subsequent molecular cloning of the receptor cDNA revealed the existence of two subtypes of endothelin receptors [14, 15]: one designated as $\mathrm{ET}_{\mathrm{A}}$ subtype that prefers endothelin-1 over endothelin3 and is expressed in vascular smooth muscle, and the other designated as $\mathrm{ET}_{\mathrm{B}}$ subtype that shows an equal affinity for endothelin-1 and endothelin-3 and is expressed in endothelial cells. Thus, these findings are consistent with the idea that the vasoconstrictor activity of endothelin- 1 is mediated through $\mathrm{ET}_{\mathrm{A}}$ receptor and the vasodilator activity through $\mathrm{ET}_{\mathrm{B}}$ receptor $[2,4]$.

However, a more complex view regarding the functional differences of the two types of endothelin receptors expressed in the vascular wall is emerging from recent studies in several laboratories employing newly discovered pharmacological probes. In these reports [22-26] they have shown that prior administration of a highly selective $\mathrm{ET}_{\mathrm{A}}$-receptor antagonist $\mathrm{BQ}-123$ (cyclo [D-Glu-LAla-D-allo-Ile-L-Leu-D-Trp]) [17] to rats inhibits both the magnitude and duration of pressor response, but not depressor response by endothelin-1, confirming that the systemic vasoconstriction by endothelin-1 is indeed mediated by $\mathrm{ET}_{\mathrm{A}}$ receptors. However, there were striking regional difference noted in the susceptibility to BQ-123 [24, 25]. Thus, endothelin-1-induced vasoconstrictions of the carotid and iliac beds were greatly inhibited by pretreatment with $\mathrm{BQ}-123$. In contrast, endothelin-1-induced vasoconstrictions of the celiac, mesenteric and renal beds were much more resistant to $\mathrm{BQ}-123$; especially, the celiac and renal vasoconstrictions were not significantly suppressed by $\mathrm{BQ}-123$ at the dose which nearly completely blocked the carotid and iliac vasoconstrictions. Moreover, intravenous injection of a $\mathrm{ET}_{\mathrm{B}}$-selective agonist, $\left[\mathrm{Ala}^{1,3,11,15}\right]$ endothelin-1 induced an initial marked vasodilation followed by a very small vasoconstriction in the carotid and iliac vascular beds, whereas in the celiac, mesenteric and renal bed this agonist caused a weak vasodilation and a following potent vasoconstriction [25]. Pretreatment with BQ-123 did not affect either initial vasodilation or the second vasoconstriction in response to $\left[\mathrm{Ala}^{1,3,11,15}\right.$ ]endothelin- 1 in these vascular beds [25]. Thus, the effects of endothelin1 and its analogues on vascular beds vary in a complex manner depending upon the time and the vascular region. These observations strongly suggest that in rats, the endothelin-1-induced vasodilation is mediated by $\mathrm{ET}_{\mathrm{B}}$ receptor in endothelial cells and that the endothelin-1induced vasoconstriction is mediated in the carotid and iliac beds by $\mathrm{ET}_{\mathrm{A}}$ receptors and in the celiac, mesenteric and renal beds largely by $\mathrm{ET}_{\mathrm{B}}$ receptors. In accordance with this notion, it was shown that significant portions of the endothelin-1- 
induced contraction of isolated vascular segments from various regions were resistant to $\mathrm{BQ}-123$ [27, 28]. In particular, in rabbit jugular veins endothelin-1 and endothelin-3 were equipotent constrictors, and $\mathrm{BQ}-123$ at up to $10 \mu \mathrm{M}$ was totally ineffective in inhibiting endothelin-1-induced contraction [28]. These composite findings suggest that vascular smooth muscle express both $\mathrm{ET}_{\mathrm{A}}$ and $\mathrm{ET}_{\mathrm{B}}$ receptors to various degrees depending on the vascular region $[29,30]$ and that stimulation of either subtype causes contraction. Especially, vascular smooth muscle of certain venous vascular regions including jugular and saphenous veins [31], and mesenteric and renal beds [24-26] appears to dominantly express ET $_{B}$-receptors. Thus, the heterogeneity of the distribution of two ET receptor subtypes in the vascular system may well account for the reported regional differences in the hemodynamic responses to $\mathrm{BQ}-123$ and $\left[\mathrm{Ala}^{1,3,11,15}\right]$ endothelin-1.

Several previous reports $[32,33]$ suggested that there may exist an additional class $\left(\mathrm{ET}_{\mathrm{C}}\right)$ of endothelin receptors which shows a higher affinity for endothelin-3 as compared to endothelin-1. It remains possible that the third receptor subtype which is stimulated by $\left[\mathrm{Ala}^{1,3,11,15}\right]$ endothelin-1 but insensitive to $\mathrm{BQ}-123$ might mediate the endothelin-1-induced vasoconstriction in the mesenteric and renal vascular beds. However, the results of genomic Southern blot analysis [34] did not support this possibility. Southern blot analysis of human genomic DNA performed under a low strigency condition with either human $\mathrm{ET}_{\mathrm{A}}$ or $\mathrm{ET}_{\mathrm{B}}$ receptor $\mathrm{CDNA}$ as probe revealed the existence of two hybridizing genomic DNA fragments which probably corresponded to the $\mathrm{ET}_{\mathrm{A}}$ and $\mathrm{ET}_{\mathrm{B}}$ receptor genes. Therefore, the third endothelin receptor, if it actually exists, should have little similarity to $\mathrm{ET}_{\mathrm{A}}$ and $\mathrm{ET}_{\mathrm{B}}$ receptors.

\section{Potential Role in Hypertension and Vasospasm}

Several lines of evidence suggest the pathogenetic role of endothelins in hypertension: first, endothelin infusion causes a sustained pressor response in experimental animals [1]; second, administration of antibodies raised against endothelin-1 lowers blood pressure in spontaneously hypertensive rats [35]; third, several reports demonstrate that plasma concentration of endothelin-1 is elevated in patients with essential hyperten- sion [36, 37], although this observation is still controversial; fourth, patients with hemangioendothelioma showed changes in blood pressure concomitantly with changes in plasma endothelin1 level before and after surgical resection of tumors [38]; and fifth, endothelin- 1 is considered to be released mainly abluminally from the endothelium [39], which may allow released endothelin- 1 to act on the underlying smooth muscle layer as a local regulator of vascular tone. However, a recent study [23] using a selective $\mathrm{ET}_{\mathrm{A}}$ receptor antagonist, $\mathrm{BQ}-123$, demonstrated that the blockade of $\mathrm{ET}_{\mathrm{A}}$ receptors by intravenous administration of this antagonist at the dose which had a profound inhibitory effect on endothelin-1induced pressor response had only a mild hypotensive effect in spontaneously hypertensive rats and DOCA-salt hypertensive rats, and no significant effect in two other hypertension models of two kidney-one clip rats and aortic ligated rats. These findings suggest that endothelin- 1 is not a major contributing factor to the maintenance of high blood pressure in these four hypertension models. Further, several laboratories reported the effects of BQ-123 administration on the basal blood pressure in normal rats. Two groups [25, 26] demonstrated that bolus or continuous infusion of BQ-123 induced a significant but relatively small decrease in mean arterial pressure in anesthetized rats, whereas three other groups [22-24] showed that bolus or continuous infusion of BQ-123 at comparable doses did not alter basal arterial pressure in conscious or anesthetized rats. Very recently Kurihara et al. [40] reported the generation of mice deficient for endothelin-1 using the technique of homologous recombination of the gene. Unexpectedly, a small increase in the blood pressure was observed in mice heterologous for the mutated endothelin-1 gene compared with normal mice. Homologous mice died shortly after birth for unknown reasons. It awaits further investigation to determine the role of endothelin-1 as a local factor in the peripheral regulation of the basal vascular tone.

Administration of endothelin- 1 and endothelin3 into the cerebral ventricles of conscious rats induces the pressor response accompanied by increases in plasma levels of vasopressin, catecholamine and ACTH [41-43]. Intracisternal administration of endothelin-1 or endothelin-3 also evokes pressor response followed by depressor 
response, and the responsible area for this response is localized to the ventral surface of the medulla [44-46]. Studies using ganglion blockers and receptor blockers indicate that the pressor response evoked by centrally administered endothelins is mediated by an increase in the sympathetic activity. Interestingly, central administration of brain natriuretic peptide attenuates endothelin-induced pressor response just as it antagonizes centrally administered angiotensin IIinduced pressor response [43]. These observations suggest that endothelins locally produced in the central nervous system may participate in the central control of circulation. It remains to be elucidated whether the endothelin/receptor system in the central nervous system plays any pathogenetic role in the development or the maintenance of hypertension.

Cerebral vasospasm is one of the most serious complications of subarachnoid hemorrhage and exerts a profound deleterious effect on the cerebral circulation. Several studies [47-49] suggested a potential role of endothelins in vasospasm after subarachnoid hemorrhage. It was reported that the level of endothelin- 1 in the cerebrospinal fluid is elevated in patients after subarachnoid hemorrhage and in canine models of subarachnoid hemorrhage [50]. Intracisternal injection of endothelin-1 (5-500 pmol) in dogs and cats evoked a long-lasting constriction of cerebral basilar artery while injection of endothelin-1 (up to $3000 \mathrm{pmol}$ ) into vertebral artery was without any vasoconstrictive effect [48]. Very recently, intracisternal injection of BQ-123 was shown in vivo to alleviate late spasm of basilar artery after subarachnoid hemorrhage in dogs [51]. Interestingly, however, administration of BQ-123 did cause a similar extent of vasodilation of normal basilar artery in control dogs, suggesting that $\mathrm{ET}_{\mathrm{A}}$ receptors are involved in the maintenance of basal tone of basilar artery. This finding is not surprising because the cerebral vascular tone is thought to be relatively independent of the regulation by autonomic nerve and circulating vasoactive substances as compared to other regions of vascular beds, but rather strongly dependent on the inherent autoregulatory mechanism. Moreover, vasospasm after subarachnoid hemorrhage is different from endothelin-1induced contraction of cerebral arteries in that vasospasm is quite resistant to a dihydropydropyridine $\mathrm{Ca}^{2+}$ channel antagonist unlike endothelin-1- induced vasoconstriction [53]. From all these data, it appears to be reasonable to think that endothelin-1 does not play a major role in the pathogenesis of cerebral vasospasm at least in a canine model of subarachnoid hemorrhage.

\section{Possible Role in Atherosclerosis and Vascular Smooth Muscle Proliferation}

Atherosclerosis may be initiated by endothelial injury, which then leads to the migration and proliferation of intimal smooth muscle. A variaty of cell types at the site of injury, including smooth muscle cells, macrophages, activated platelets and endothelial cells are capable of releasing a number of growth promoting molecules for smooth muscle such as PDGF, basic FGF, EGF and thrombin [53]. It is an intriguing possibility that endothelin-1 released from the endothelium could also serve as a causative factor for atherogenesis, since the expression of endothelin- 1 in endothelial cells is stimulated by thrombin, TGF- $\beta$, increased shear stress and hypoxia which may accumulate in conditions associated with endothelial injury $[2,4]$. Interestingly, endothelin-1-immunoreactivity was demonstrated in medial smooth muscle as well as the endothelium in atherosclerotic arteries, whereas in normal arteries it was detected only in the endothelium [54]. Moreover, growing evidence indicate that endothelins possess mitogenic potencies. Komuro et al. [55] first reported in cultured rat aortic smooth muscle cells that endothelin-1 stimulates DNA synthesis only when insulin was present together with endothelin-1, suggesting that endothelin-1 acts as a competence type of growth factor on vascular smooth muscle cells. Bobik et al. [56] showed that DNA synthesis started as early as $8 \mathrm{~h}$ after addition of endothelin-1 to quiescent rat aortic smooth muscle cells, suggesting that its activity is due to a direct mitogenic effect of endothelin-1 on vascular smooth muscle cells. Recently, Eguchi et al. [57] have reported that rat aortic vascular smooth muscle cells passaged more than 30 times express a higher level of $\mathrm{ET}_{\mathrm{B}}$ endothelin receptor mRNA than younger cells and that endothelin-1 exhibits a much more potent mitogenic activity in older cells compared with younger cells, suggesting that $\mathrm{ET}_{\mathrm{B}}$ endothelin receptors may mediate the mitogenic action of endothelin-1 more effectively in this cell type. On the basis of these observations, it is tempting to 
speculate that endothelin- 1 accumulated at the site of endothelial injury exerts a mitogenic effect on vascular smooth muscle in a paracrine or autocrine fashion and contributes to atherogenesis.

\section{Mechanisms of Endothelin Action}

\section{(1) Vascular smooth muscle contraction}

Endothelin-1 induces a dose-dependent contractions of isolated vascular segments from experimental animals and human mainly by directly acting on smooth muscle [1], with a few exceptions [19-21]. Like most of vasoactive receptor agonists including norepinephrine, angiotensin II, serotonin and histamine, the receptor activation by endothelins causes the gating of $\mathrm{Ca}^{2+}$ channels and the activation of phospholipase $\mathrm{C}$ which catalyzes the hydrolysis of phosphatidylinositol4,5-bisphosphate $\left(\mathrm{PIP}_{2}\right)$ to give rise to inositol1,4,5-trisphosphate $\left(\mathrm{IP}_{3}\right)$ and 1,2-diacylglycerol (DAG) [58-60]. IP 3 acts as a second messenger to mobilize $\mathrm{Ca}^{2+}$ from an intracellular pool [61], and an increase in the DAG content activates protein kinase C [62]. Phospholipase D-catalyzed breakdown of phospholipids may also contribute to accumulation of DAG in cells stimulated with endothelin [63]. In many cases receptor stimulation by $\mathrm{Ca}^{2+}$ mobilizing agonists is coupled to phospholipase $\mathrm{C}$ activation via guanine nucleotide binding regulatory proteins ( $G$ proteins) $[60]$. It was first demonstrated, in membranes prepared from rat aortic smooth muscle A-10 cells which express abundant $\mathrm{ET}_{\mathrm{A}}$ endothelin receptors, that endothelin-1 stimulates phospholipase C-catalyzed polyphosphoinositide hydrolysis in a manner strictly dependent on a nonhydrolyzable GTP analogue, GTP $\gamma$ S [64]. Further, GTP $\gamma S$ inhibits specific binding of ${ }^{125}$ I-endothelin-1 to A-10 cell membranes in a dose-dependent manner [64]. The inhibitory modulation by guanine nucleotides of the binding of various agonists to their respective receptors is a well-known characteristic found in the receptors that interact with $G$ proteins. These results strongly suggest that the $\mathrm{ET}_{\mathrm{A}}$ endothelin receptor in vascular smooth muscle is coupled to phospholipase $\mathrm{C}$ via a $\mathrm{G}$ protein. Indeed the molecular cloning of the $\mathrm{ET}_{\mathrm{A}}$ endothelin receptor revealed the transmembrane topology characteristic of the $G$ protein-coupled receptor superfamily [14]. Pretreatment of A-10 cells with pertussis toxin which is known to inactivate Gi and
Go proteins does not significantly affect the endothelin-1-induced stimulation of phospholipase C [64]. Although further studies are required to conclusively identify the $G$ protein species that couples $\mathrm{ET}_{\mathrm{A}}$ endothelin receptors to phospholipase $\mathrm{C}$, the members of $\mathrm{Gq}$ family $\left(\mathrm{Gq}, \mathrm{G}_{11}, \mathrm{G}_{14}\right.$, $G_{16}$ ) are likely candidates, as suggested for many other Ca-mobilizing $\mathrm{G}$ protein-coupled receptors [65].

As described above, both in vitro contraction studies using isolated vascular strips [22, 23] and hemodynamic studies in intact animals [24-26] suggest that the endothelin-induced vasoconstriction in certain vascular beds is mediated by $\mathrm{ET}_{\mathrm{B}}$ endothelin receptors in vascular smooth muscle. Although the signal transduction mechanisms via $\mathrm{ET}_{\mathrm{B}}$ endothelin receptors in vascular smooth muscle has not yet been defined, there are several non-smooth muscle cell types in which the signal transduction mechanism via $\mathrm{ET}_{\mathrm{B}}$ endothelin receptor was characterized. In $\mathrm{CHO}$ cells stably transfected with the $\mathrm{ET}_{\mathrm{B}}$ receptor cDNA [66], and bovine vascular endothelial cells [32] and rat osteosarcoma cells constitutively expressing $\mathrm{ET}_{\mathrm{B}}$ receptors, endothelins stimulate phospholipase $\mathrm{C}$ like in cells expressing $\mathrm{ET}_{\mathrm{A}}$ receptors. In $\mathrm{ET}_{\mathrm{B}}$ receptor-expressing rat osteosarcoma cells endothelin-1-induced stimulation of phospholipase $\mathrm{C}$ is insensitive to pertussis toxin (unpublished observation). In contrast, in bovine endothelial cells it was reported that endothelin-3-induced stimulation of phospholipase C was totally abolished by pertussis toxin pretreatment [32]. These observations indicate that the endothelin receptor$\mathrm{G}$ protein coupling may vary among cell types and receptor subtypes.

When the intracellular free $\mathrm{Ca}^{2+}$ concentration $\left(\left[\mathrm{Ca}^{2+}\right] \mathrm{i}\right)$ is measured in intact porcine coronary smooth muscle strips with the photoprotein, aeguorin, there is a biphasic increase in $\left[\mathrm{Ca}^{2+}\right] \mathrm{i}$ upon endothelin- 1 stimulation [60]. The $\left[\mathrm{Ca}^{2}+\right] \mathrm{i}$ rapidly rises to a peak within $1 \mathrm{~min}$, then falls to a plateau level slightly higher than the unstimulated baseline value. In the absence of extracellular $\mathrm{Ca}^{2+}$, endothelin-1 stimulation causes a smaller initial transient increase in $\left[\mathrm{Ca}^{2+}\right] \mathrm{i}$, which is most likely caused by $\mathrm{IP}_{3}$-induced mobilization of intracellular $\mathrm{Ca}^{2+}$. These findings indicate that $\mathrm{Ca}^{2+}$ giving rising to the initial transient response comes from both intracellular and extracellular sources and that the sustained small increase in $\left[\mathrm{Ca}^{2+}\right] \mathrm{i}$ is 
dependent on extracellular $\mathrm{Ca}^{2+}$, i.e. $\mathrm{Ca}^{2+}$ influx across the plasma membrane. Removal of extracellular $\mathrm{Ca}^{2+}$ or additions of inorganic $\mathrm{Ca}^{2+}$ channel blockers substantially but not completely inhibit endothelin-1-induced contraction in many vascular regions, indicating that the major portion of the endothelin-induced contraction is dependent on $\mathrm{Ca}^{2+}$ influx across the plasma membrane $[59,67]$. Since endothelin-1-induced contraction of porcine coronary artery strips in markedly inhibited by a dihydropyridine $\mathrm{Ca}^{2+}$ channel antagonist $[1,60,68]$, endothelin-1-induced $\mathrm{Ca}^{2+}$ influx appears to occur mainly through voltagedependent $\mathrm{Ca}^{2+}$ channels of L-type. In fact, endothelin-1 has been shown to activate the dihydropyridine-sensitive, voltage-dependent $\mathrm{Ca}^{2+}$ channel in porcine coronary artery smooth muscle cells with a patch-clamp technique [60, 69]. Based upon the high sensitivity to a dihydropyrine $\mathrm{Ca}^{2+}$ channel antagonist observed in porcine coronary artery, it was initially hypothesized that endothelin-1 was an endogenous agonist of the dihydropyridine-sensitive $\mathrm{Ca}^{2+}$ channel [1]. However, it was later noted that isolated vascular segments from other vascular regions, for example rabbit aorta and porcine carotid artery, are not always inhibited by a dyhydropyridine $\mathrm{Ca}^{2+}$ channel antagonist [67]. In addition, in coronary artery smooth muscle, serotonin-and histamine-induced contractions are also sensitive to a dihydropyridine $\mathrm{Ca}^{2+}$ channel antagonist [70]. On the other hand, in rabbit aorta serotonin-and histamine-induced contraction as well as endothelin-1-induced contraction are resistant to a dihydropyridine $\mathrm{Ca}^{2+}$ channel antagonist. These observations indicate that the high sensitivity to a dihydropyridine $\mathrm{Ca}^{2+}$ channel antagonist of the endothelin-1-induced contraction of porcine coronary artery smooth muscle represents the tissue-specific rather than the agonist-specific property. One of the factors which determine the region-specific sensitivity to a dihydropyridine $\mathrm{Ca}^{2+}$ antagonist may be a resting level of a membrane potential which affects the conformation of a L-type $\mathrm{Ca}^{2+}$ channel protein, a target molecule of a dihydropyridine drug, as suggested by Godfraind et al. [71]. Porcine coronary artery smooth muscle responds to endothelin-1 stimulation with only a small extent of membrane deporalization $(8-15 \mathrm{mV})$ [68] which is brought about probably by stimulation of inward $\mathrm{Na}^{+}$current and/or outward $\mathrm{Cl}^{-}$current, im- plying that the activation of a L-type $\mathrm{Ca}^{2+}$ channel by endothelin-1 is not accounted for solely by the membrane depolarization [72, 73]. The electrophysiological study by Silverberg et al. [69] suggested that endothelin-1 acts via the second messenger system to induce the gating of a L-type $\mathrm{Ca}^{2+}$ channel in porcine cornary artery smooth muscle.

When endothelin-1 is added to porcine coronary artery smooth muscle, $20 \mathrm{kD}$ myosin light chain (MLC) becomes maximally phosphorylated within 5 min by activation of a $\mathrm{Ca}^{2+}$, calmodulindependent enzyme, MLC kinase, and stays at this level as long as the isometric contraction is sustained for at least $60 \mathrm{~min}[74,75]$. When the temporal changes in the extent of phosphorylation of $20 \mathrm{kD}$ MLC is compared with that in $\left[\mathrm{Ca}^{2+}\right] \mathrm{i}$, it is apparent that during the sustained phase of contraction the level of $20 \mathrm{kD}$ MLC phosphorylation is maintained at a lower $\left[\mathrm{Ca}^{2+}\right] \mathrm{i}$ compared to the $\left[\mathrm{Ca}^{2+}\right] \mathrm{i}$ during the initial phase of contraction. The apparent sensitization of phosphorylation of $20 \mathrm{kD}$ MLC during the sustained phase of endothelin-1-induced contraction may be caused by a GTP-dependent mechanism as shown in norepinephrine-and carbachol-induced smooth muscle contraction [76, 77]. Although the involvement of a small molecular weight $G$ protein rho p21 [78], MLC-specific phosphatase [77] and protein kinase $C[76,79]$ in this sensitization phenomenon has been suggested, precise molecular mechanism underlying the sensitization remains to be clarified.

Several lines of evidence suggest that activation of the protein kinase $\mathrm{C}$ may also participate in the contractile mechanism activated by endothelin-1: first, stimulation of porcine coronary artery smooth muscle causes an increase in the tissue content of DAG [68], which is an endogenous activator of the protein kinase $\mathrm{C}$, second, stimulation with endothelin- 1 causes a sustained increase in the membrane-associated protein kinase $\mathrm{C}$ activity with a reciprocal decrease in the cytosolic protein kinase C activity [80], third, endothelin-1 induces a small but significant contraction even after strict $\mathrm{Ca}^{2+}$ depletion from both intra- and extracellular pools and this contraction is inhibited by a protein kinase C inhibitor, $\mathrm{H}-7$ [68, 136], fourth, endothelin-1 induces phosphorylation of a thin filament associated protein, caldesmon and an intermediate filament protein, desmin [74, 75], 
fifth, an activator of protein kinase C, phorbol ester causes a potent contraction and phosphorylation of caldesmon and desmin in porcine coronary artery smooth muscle [75]. Although the precise molecular mechanism underlying the protein kinase C-dependent contraction is not yet fully understood [77, 81], these observations suggest that the protein kinase $\mathrm{C}$ signalling pathway together with the sustained increase in the content of phosphorylated $20 \mathrm{kD}$ MLC may mediate the endothelin-1-induced contraction (Fig. 1).

\section{(2) Endothelium-dependent vasorelaxation}

Endothelins stimulate release of vasodilator prostanoids and EDRF from the endothelium [5], which may mediate the vasodilator and the antiplatelet activities of the peptides. The demonstration of the binding property of ${ }^{125}$ I-labeled endothelin isopeptides to endothelial cell membranes which is compatible with the existence of $\mathrm{ET}_{\mathrm{B}}$ receptors $[32,82]$, the activity of a selective $\mathrm{ET}_{\mathrm{B}}$ agonist in stimulating EDRF production [25, 83], and the expression of the $\mathrm{ET}_{\mathrm{B}}$ endothelin receptor message but not of the $\mathrm{ET}_{\mathrm{A}}$ receptor message by Northern blot analysis [29, 30] is all consistent with the notion that $\mathrm{ET}_{\mathrm{B}}$ endothelin receptor mediate the endothelin actions on the endothelium. The activation of $\mathrm{ET}_{\mathrm{B}}$ endothelin receptors by endothelins causes activation of phospholipase $\mathrm{C}$ and phospholipase $\mathrm{A}_{2}$, and gating of a non-voltagedependent $\mathrm{Ca}^{2+}$ channel [32]. The resulting increase in $\left[\mathrm{Ca}^{2+}\right] \mathrm{i}$ activates a $\mathrm{Ca}^{2+}$, calmodulindependent isoform (type III) of nitric oxide synthase and induces release of NO (EDRF) [84]. Released NO acts on the underlying smooth muscle layer and activates a soluble guanylate cyclase to generate cyclic GMP [85]. An increase in the intracellular cyclic GMP level induces relaxation of vascular smooth muscle by inhibiting agonist-induced activation of phospholipase $\mathrm{C}$ and $\mathrm{Ca}^{2+}$ channel gating and by activating $\mathrm{Ca}^{2+}$ extrusion across the plasma membrane [85]. The first

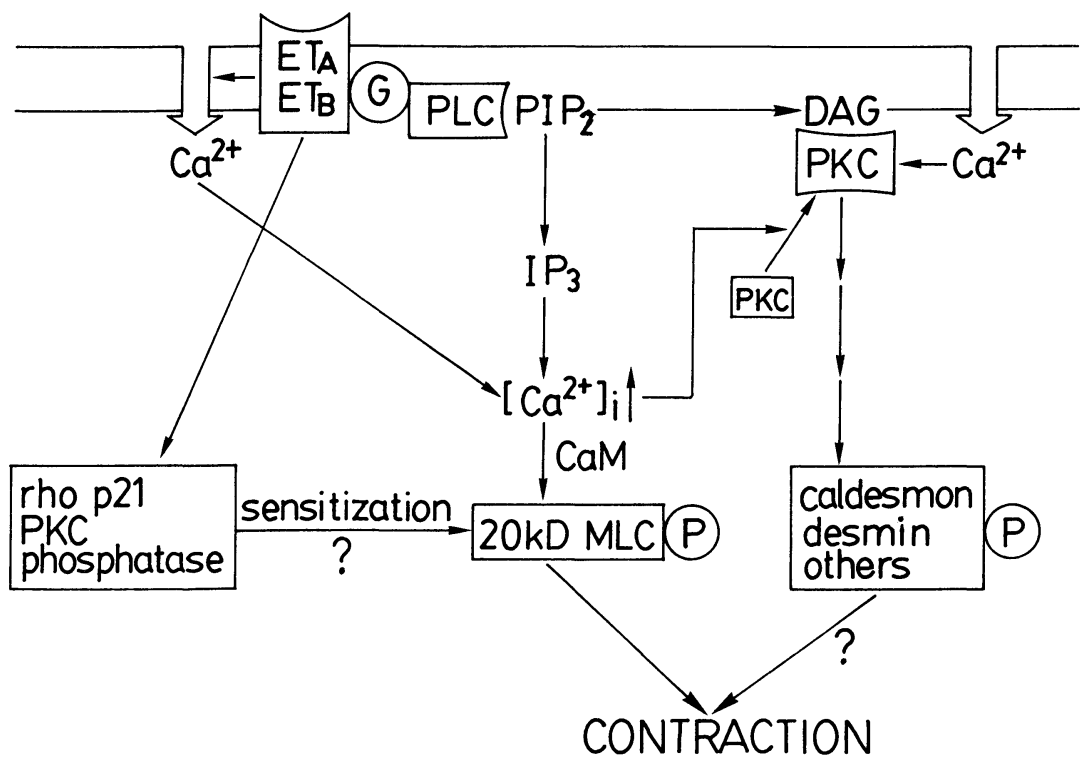

Fig. 1. Mechanisms of vascular smooth muscle contraction caused by endothelins. The binding of endothelins to either $\mathrm{ET}_{\mathrm{A}}$ or $\mathrm{ET}_{\mathrm{B}}$ endothelin receptors on vascular smooth muscle cells activates phospholipase $\mathrm{C}$ in a $\mathrm{G}$ protein (G)-coupled manner and causes gating of $\mathrm{Ca}^{2+}$ channels, leading to the generation of inositol-1, 4, 5-trisphosphate $\left(\mathrm{IP}_{3}\right)$ and 1, 2-diacylglycerol (DAG), a protein kinase C (PKC) activator, and to stimulation of $\mathrm{Ca}^{2+}$ influx. Increase in $\left[\mathrm{Ca}^{2+}\right] \mathrm{i}$ activates a $\mathrm{Ca}^{2+}$, calmodulin-dependent myosin light chain (MLC) kinase, resulting in phosphorylation (P) of $20 \mathrm{KD}$ light chain subunit (MLC) of myosin which allows interaction with actin leading to the initiation of contraction. The receptor activation by endothelins may somehow stimulate the sensitizing mechanism for phosphorylation of myosin to an increase in $\left[\mathrm{Ca}^{2+}\right]$ i. The activation of protein kinase $\mathrm{C}$ causes increases in phosphorylation levels of several proteins which may also contribute to the contraction. See the text for more detail. 
step for the production of vasodilator prostanoids is cleavage and release of arachidonic acid by cytosolic type of phospholipase $\mathrm{A}_{2}\left(\mathrm{CPLA}_{2}\right)$ from the membrane phospholipids. An increase in $\left[\mathrm{Ca}^{2+}\right] \mathrm{i}$ on the receptor activation by endothelins causes $\mathrm{CPLA}_{2}$ to translocate from the cytosol to the membrane. Endothelins activate a cascade of serine/threonine kinases, leading to activation of mitogen activated kinase (MAP kinase) mainly in a protein kinase C-dependent manner. The activated MAP kinase then phosphorylate $\mathrm{CPLA}_{2}$, causing an increase in cPLA ${ }_{2}$ activity [86]. Released arachidonic acid is metabolized via the cyclooxygenase pathway to prostacyclin and other vasodilator prostanoids, which act on vascular smooth muscle to cause an increase in the intracellular cyclic AMP level and relaxation (Fig. 2).

\section{(3) Mitogenic action}

In addition to vascular smooth muscle cells, endothelins stimulate DNA synthesis in several types of cells [138], including fibroblasts [87], renal mesangial cells [88], osteoblastic cells [89, 90] and several cancer cell lines [138]. Molecular mechanisms underlying endothelin-1-induced mitogenesis were studied in Swiss mouse 3T3 fibroblasts, a well characterized model system for the investigation of cell growth, in which activation of the protein kinase C induces synchronous DNA synthesis [91]. In this cell type, endothelin- 1 activates phospholipase $C$ via $\mathrm{ET}_{\mathrm{A}}$ receptors with the production of two second messengers, $\mathrm{IP}_{3}$ and $\mathrm{DAG}$, leading to $\mathrm{Ca}^{2+}$ mobilization from both intra-and extracellular pools and activation of protein kinase $\mathrm{C}$ as evidenced by phosphorylation of a protein kinase C substrate, MARCKS protein. The mitogenic effect of endothelin-1 is markely attenuated in phorbol ester-pretreated, protein kinase Cdepleted cells, suggesting that protein kinase $\mathrm{C}$ activation is a necessary, if not sufficient, event in endothelin-1 induced DNA synthesis. Swiss 3T3 cells express at lest four isoforms $(\alpha, \delta, \varepsilon$ and $\zeta)$ of the protein kinase $\mathrm{C}$, among which three of them $(\alpha, \delta$ and $\varepsilon)$ are subject to downregulation by phorbol ester-pretreatment, suggesting that either $\alpha, \delta$ and/or $\varepsilon$ isoform of the protein kinase $\mathrm{C}$ may mediate the mitogenic effect of endothelin-1 in this cell type. In Swiss 3T3 cells, the protein kinase C stimulation activates a cascade of intracellular serine/threonine kinases, leading to activation of MAP kinase. Activated MAP kinase, in turn, was recently found to phosphorylate, in addition to

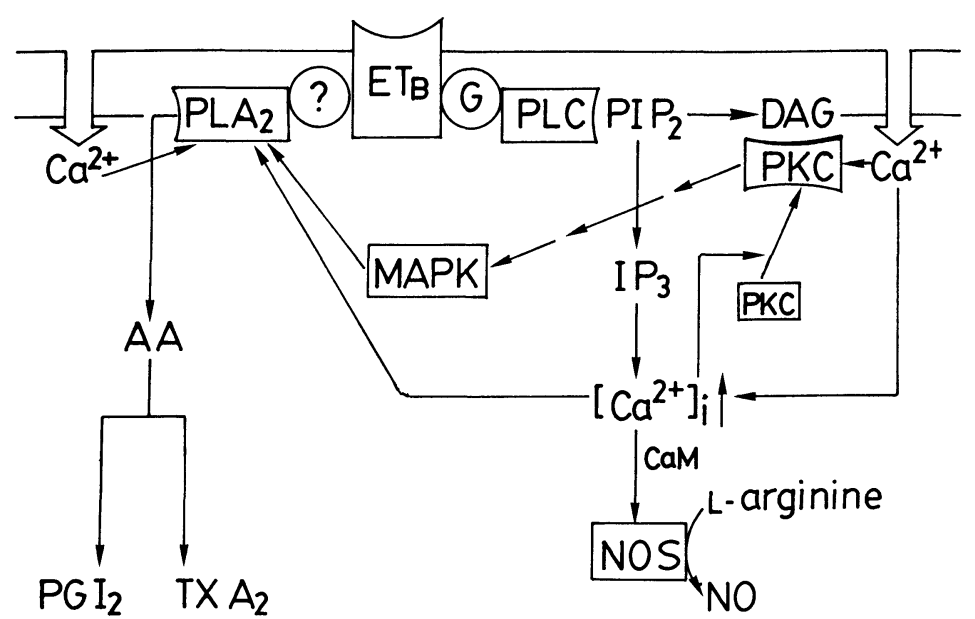

Fig. 2. Mechanisms of action of endothelins in the endothelium. Endothelins act via $\mathrm{ET}_{\mathrm{B}}$ receptors to cause activation of phospholipase $\mathrm{C}$ and gating of non-voltage-dependent $\mathrm{Ca}^{2+}$ channels, leading to an increase in $\left[\mathrm{Ca}^{2+}\right] \mathrm{i}$ and PKC activation. The PKC, in turn, activates a cascade of serine/threonine kinases causing activation of mitogen activated protein kinase (MAPK). The MAPK phosphorylates a cytosolic type of phospholipase $\mathrm{A}_{2}\left(\mathrm{PLA}_{2}\right)$ liberating arachidonic acid (AA), which is metabolized to prostaglandin $\mathrm{I}_{2}\left(\mathrm{PGI}_{2}\right)$ and thromboxane $\mathrm{A}_{2}\left(\mathrm{TxA}_{2}\right)$. Increase in $\left[\mathrm{Ca}^{2+}\right] \mathrm{i}$ activates a $\mathrm{Ca}^{2+}$, calmodulin-dependent isoform of NO synthase to lead to production of NO, endothelium-derived relaxing factor (EDRF). See the legend of Fig. 1. for the other abbrebiations. 
cPLA $_{2}$ as described above, Myc and Jun proteins, thereby enhancing their ability to stimulate gene transcription. This pathway may be involved in endothelin-1-induced expression of protooncogene c-fos, because 5' upstream region of c-fos gene contains a cis-element for Jun/Fos complex (AP-1). Moreover, it was found that stimulation of protein kinase $\mathrm{C}$ in serum-deprived, quiescent Swiss 3T3 cells results in activation of cdc2, a member of cell cycle-regulating cyclin-dependent protein kinases at a time point close to $\mathrm{Gl} / \mathrm{S}$ boundary of the cell cycle [92]. The activation of cdc2 kinase is associated with a dramatic increases in cdc2 protein level and its phosphorylation at serine/threonine residues. Cyclin dependent kinases including cdc2 and cdk2 have been shown to phosphorylate and to inactivate tumor suppressor $\mathrm{RB}$ gene product, which is now considered to be a crucial prerequisite for initiation of DNA synthesis by mammalian cells. In human vascular endothelial cells stimulation of protein kinase $\mathrm{C}$ in early G1 phase markedly potentiates growth factor-induced activation cdc2 and cdk2, as well as expression of cyclin A and E [94]. These observations suggest that activation of protein kinase $\mathrm{C}$ through the inositol lipid signalling pathway converges to the common mitogenic signalling, which, although yet to be defined, eventually leads to the initiation of DNA synthesis. The mitogenic effect of endothelin-1 is dependent also on the extracellular $\mathrm{Ca}^{2+}$ concentration. Activation of cdc2 and cdk2 kinases and phosphorylation of $\mathrm{RB}$ protein are also dependent on the extracellular $\mathrm{Ca}^{2+}$ concentration [95]. Since cdc2 and cdk2 do not require $\mathrm{Ca}^{2+}$ for in vitro kinase activity, it is conceivable that there exists $\mathrm{Ca}^{2+}$-dependent pro- cess(es) in the mitogineic signalling pathway at site(s) proximal to cdc2 and cdk2 activation. Although phospholipase $\mathrm{C}$ and protein kinase $\mathrm{C}$ are classical examples of $\mathrm{Ca}^{2+}$-dependent enzymes, activations of these enzymes are totally independent of extracellular $\mathrm{Ca}^{2+}$ [93], suggesting that the $\mathrm{Ca}^{2+}$-dependent process is located downstream of PKC action. Like many other mitogens which activate $G$ protein-coupled receptors to stimulate phospholipase C-protein kinase C signalling pathway such as bombesin/GRP and thrombin, endothelin- 1 is known to activate protein tyrosine kinase as well. This effect of endothelin may be the consequence of protein kinase $\mathrm{C}$ activation. Unlike bombesin/GRP, which synergizes with growth factors acting via the receptor tyrosine kinase activation but not with a phorbol ester, endothelin-1 shows synergistic stimulation of DNA synthesis when acting together with a phorbol ester or bombesin/GRP [96]. This observation may suggest the presence of thus far unrecognized mechanism of action of endothelin as a mitogen.

\section{Actions on Endocrine System}

Autoradiographic studies of rat tissues with ${ }^{125}$ I-labeled endothelin-1 demonstrated the specific binding sites for endothelins in endocrine organs including hypothalami, pituitaries and adrenal glands. These studies suggest modulatory roles of endothelins for endocrine functions [1, 97]. Further, in these tissues the presence of endothelin-immunoreactivity and -mRNAs was also detected. Numerous studies actually demonstrated modulatory effects of endothelin peptides

Table 1. Modulation of endocrine secretion by endothelin peptides

\begin{tabular}{|c|c|c|c|}
\hline Hormone/Substance & Effect & Tissue/cells & References \\
\hline vasopressin & stimulation & hypothalamic slice & 99 \\
\hline substance $P$ & stimulation & hypothalamic slice & 101 \\
\hline gonadotropin releasing hormone & stimulation & cultured hypothalamic neurons & 102 \\
\hline prolactin & inhibition & cultured pituitary cells & $105,107-109$ \\
\hline & biphasic (stimulation $\rightarrow$ inhibition) & cultured pituitary cells & 104,108 \\
\hline luteinizing hormone & stimulation & cultured pituitary cells & $104,107,110,111$ \\
\hline follicle stimulating hormone & stimulation & cultured pituitary cells & 107,111 \\
\hline growth hormone & stimulation & cultured pituitary cells & 104 \\
\hline thyrotropin & stimulation & cultured pituitary cells & 107 \\
\hline atrial natriuretic peptide & stimulation & atrial cardiomyocytes & $113-117$ \\
\hline aldosterone & stimulation & zona glomerulosa cells & $125-130$ \\
\hline catecholamine & stimulation & adrenal chromaffin cells & $132-134$ \\
\hline renin & inhibition & juxtaglomerular cells & 123,124 \\
\hline
\end{tabular}


on a variety of endocrine functions (Table 1); endothelins stimulate release of vasopressin and gonadotropin releasing hormones from hypothalamic neurons, several hormones from anterior pituitary cells, atrial natriuretic peptide from atrial cardiomyocytes, aldosterone and catecholamine from adrenal cells. On the other hand, endothelins inhibit release of prolactin from anterior pituitary cells and renin from juxtaglomerular cells.

\section{Stimulation of Vasopressin, Substance $P$ and Gonadotro-} pin Releasing Hormone Secretion from Hypothalamus

Systemic intravenous administration of endothelin-1 causes an increase in plasma vasopressin level in anesthetized rats and dogs [8, 18]. This occurs despite of elevated level of plasma atrial natriuretic peptide and increased left atrial pressure, which both operate to inhibit vasopressin release, suggesting that endothelin-1 may have a central stimulatory effect on vasopressin release. In fact, subsequently, intracerebroventricular injection of endothelin-1 was demonstrated to cause an increase in plasma level of vasopressin [41-43]. Systemic administration of endothelin-1 enhances the activity of vasopressin-and oxytocin-secreting neurons in the paraventricular and supraoptic nuclei as well as of neurons in the subfornical organ which lack the blood-brain barrier and send efferent neural projections to both supraoptic and paraventricular nuclei of the hypothalamus [98]. The destruction of the subfornical organ abolishes the activation of vasopressin-and oxytocinsecreting neurones in response to systemic administration of endothelin-1, suggesting that the subfornical organ is a site at which endothelin-1 acts in the central nervous system to elicit vasopressin release [98]. It is controversial whether endothelins have any direct effect on vasopressinsecreting neurons in the hypothalamus [99, 100]. Yoshizawa et al. [103] reported that magnocellular neurones with projections to the median eminence and the posterior pituitary contained endothelin1-immunoreactivity and that endothelin-1immunoreactivity disappeared in the posterior pituitary of rats which were water-deprived for four days, suggesting a release of endothelin-1 under a physiological condition [11]. Endothelin-1 immunoreactivity was found to be co-localized with vasopressin or oxytocin in the neurosecretory granule of the axon. However, it is not known whether endothelin-1 is released from the posterior pituitary to enter the systemic circulation exerting its action as a hormone or to act locally in a paracrine or autocrine manner. Interestingly, endothelin- 1 and -3 were shown to act to antagonize the antidiuretic action of vasopressin in the renal collecting duct, suggesting the negative feedback interaction of endothelins with vasopressin at the level of the peripheral target organ of vasopressin $[9,135]$.

Endothelin-1 stimulates release of substance $P$ from perfused isolated hypothalamic slice [101]. This effect was reported to be unaffected by removal of extracellular $\mathrm{Ca}^{2+}$. On the basis of morphological studies showing that substance Pimmunoreactive nerve terminals are localized in eminentia medialis of the hypothalamus [102], it is conceivable to postulate that substance $\mathrm{P}$ is thought to be secreted from neuroendocrine cells in the hypothalamus into portal vein to reach the anterior pituitary, where it may affect the pituitary function. The effect of endothelin-1 in the spinal cord was reported to be inhibited by a substance P-receptor antagonist, Spantide, implying that the action of endothelin-1 in the central nervous system might be, in part, mediated by substance $P$ [11].

Endothelin-1 stimulates secretion of gonadotropin releasing hormone from cultured hypothalamic neurons derived from fetal rats [102]. Relative potencies of endothelin-1 and endothelin-3 in displacing ${ }^{125}$ I-endothelin-1 binding to membranes, in activation of phospholipase $\mathrm{C}$, and in the secretory response suggest that the $\mathrm{ET}_{\mathrm{A}}$ receptor mediate the action of endothelin peptides on hypothalamic neurons. Interestingly, the same culture of hypothalamic cells was observed to secrete both endothelin-1 and endothelin-3 [102]. Since endothelins are also known to have a direct stimulatory action on gonadotroph cells as described below, endothelins appear to act at two sites to stimulate gonadotropin secretion.

\section{Modulation of Secretion of Anterior Pituitary Hormones}

Several groups reported conflicting data concerning the endothelin effects on release of prolactin (PRL), luteinizing hormone (LH), follicle stimulating hormone (FSH) and other anterior pituitary hormones from cultured rat pituitary cells. In particular, the reported data on PRL 
secretion are quite confusing. Samson et al. [104] demonstrated that endothelin-3 $(1-100 \mu \mathrm{M})$ induced a monophasic inhibition of PRL secretion in the static incubation system of cultured anterior pituitary cells from adult rats. When a more physiological perfusion system was employed, they found that endothelin-3 at $100 \mu \mathrm{M}$ induced a biphasic response of PRL secretion: a transient stimulation followed by a longer-lasting inhibition. In the perfusion system, endothelin-3 also stimulated secretion of $\mathrm{LH}$ and growth hormone $(\mathrm{GH})$. They showed that endothelin-1 was ineffective in eliciting the inhibition of PRL secretion in the static incubation system [105]. However, one of these authors reported later that the rank order of potency for the inhibition of PRL secretion was endothelin- $1=$ endothelin-2 $>$ endothelin-3 and that the selective $\mathrm{ET}_{\mathrm{A}}$ receptor antagonist, $\mathrm{BQ}$ 123, abolished the inhibitory effect of endothelins for PRL secretion, suggesting the role of $\mathrm{ET}_{\mathrm{A}}$ receptors in this response [106]. Kanyicska et al. demonstrated that endothelin-3 dose-dependently inhibited PRL secretion and stimulated secretion of LH, FSH and thyrotropin, without affecting $\mathrm{GH}$ secretion in the static incubation system of cultured anterior pituitary cells from adult rats. Dymshitz et al. [108] showed that the cultivation of anterior pituitary cells in serum-containing medium caused a monophasic inhibition of PRL secretion upon endothelin stimulation in the static incubation system with endothelin-1 being a more potent inhibitor than endothelin-3, while the cultivation in serum-free medium caused a biphasic response, indicating that serum had a profound influence on the response of PRL release to endothelins. Domae et al. [109], however, demonstrated that endothelin-1 and endothelin-3 inhibited PRL release from isolated rat anterior pituitary slice with an almost identical potency, suggesting the involvement of $\mathrm{ET}_{\mathrm{B}}$ receptors. Further, Stojilkovic et al. $[110,111]$ reported that endothelin- 1 is more potent in eliciting $\left[\mathrm{Ca}^{2+}\right] \mathrm{i}$ response and $\mathrm{LH}$ secretion and in binding to the membrane than endothelin-3 in cultured anterior pituitary cells from adult rats, suggesting that these responses by endothelins occurred via activation of $\mathrm{ET}_{\mathrm{A}}$ receptors. The reasons for these discrepancies are not known at present.

It was reported that either intracerebroventricular injection or systemic intravenous administration of endothelin-3 at a pressor dose did not significantly alter plasma levels of PRL, LH and $\mathrm{GH}$ in rats, suggesting that endothelins of peripheral origin are unlikely to act within the pituitary. As mentioned above, endothelin-1immunereactivity is detected in hypothalamic neurons which project to the median eminence [103]. This observation suggests that endothelin-1 secreted from neuroendocrine cells in the hypothalamus into portial vein reaches the anterior pituitary, where it may have a direct action on the functions of anterior pituitary cells. Alternatively, locally produced endothelins may act as a paracrine or autocrine regulator of pituitary functions, because both endothelin- 1 and endothelin-3 are shown to be present in the pituitary. Particularly, the pituitary is unique in that it contains a larger amount of endothelin-3 than endothelin-3 [137].

Endothelins were shown to stimulate phospholipase $\mathrm{C}$, generating $\mathrm{IP}_{3}$ and $\mathrm{DAG}$ and to cause a biphasic increase in $\left[\mathrm{Ca}^{2+}\right] \mathrm{i}$ in rat anterior pituitary cells, as in other types of cells $[110,111]$. A dihydropyridine $\mathrm{Ca}^{2+}$-channel antagonist, nifedipine, inhibits both the extracellular $\mathrm{Ca}^{2+}$ dependent phase of the $\left[\mathrm{Ca}^{2+}\right] \mathrm{i}$ response and $\mathrm{LH}$ secretion in gonadotroph $[104,111]$ cells. Pretreatment of anterior pituitary cells with pertussis toxin abolished the inhibitory effect of endothelin-3 on PRL release, indicating the involvement of pertussis toxin-sensitive $\mathrm{G}$ proteins (Gi or Go) in the this action of endothelin-3 [112]. It is an interesting possibility that this inhibitory response is caused by inhibitions of adenylate cyclase activity and/or $\mathrm{Ca}^{2+}$ channel activity through endothelin receptor-G protein coupling, as demonstrated for dopamine and somatostatin actions on pituitary cells.

\section{Stimulation of Atrial Natriuretic Peptide Secretion}

Intravenous infusion of endothelin-1 causes elevation of plasma level of atrial natriuretic peptide (ANP) [8, 18]. ANP secretion from mammalian hearts is known to be augmented by a variety of stimuli, including elevation in left atrial pressure, tachycardia, and neurotransmitters and hormones such as norepinephrine and neuropeptide $\mathrm{Y}$. One of the responsible mechanisms for ANP release caused by endothelin-1 infusion is a rise in left atrial pressure which occurs during endothelin- 1 infusion. In addition to this, endothelin- 1 directly acts on atrial cardiac muscle 
to stimulate ANP release. This effect was demonstrated in cultured atrial cardiomyocytes [113] and isolated atria [114]. In rat atria, endothelin-1 enhances the ANP secretory response to stretch, implying that the direct action of endothelins on atrial muscle coordinately interacts with elevation of left atrial pressure to enhance atrial ANP secretion [117].

Endothelin-1 induces a dose-dependent increase in $\left[\mathrm{Ca}^{2+}\right] \mathrm{i}$ in atrial cells. The releasing effect of endothelin- 1 is inhibited by a reduction in extracellular $\mathrm{Ca}^{2+}$ and addition of either a blocker of voltage-dependent $\mathrm{Ca}^{2+}$ channels, a calmodulin antagonist calmidazolium or a protein kinase $\mathrm{C}$ inhibitor staurosporine $[115,116]$. These observations suggest the importance of $\mathrm{Ca}^{2+}$ influx across the plasma membrane through a voltagedependent $\mathrm{Ca}^{2+}$ channel, calmodulin and protein kinase $\mathrm{C}$ in endothelin-induced ANP secretion.

Interestingly, ANP antagonizes the actions of endothelins at several site. First, endothelin- 1 is a potent vasoconstrictor while ANP is a vasodilator. Second, endothelin-1 has a potent antinatriuretic effect in the kidney while ANP causes natriuresis. Third, endothelin-1 stimulates aldosterone secretion from adrenal glomerulosa cells while ANP inhibits aldosterone secretion. Fourth, centrally administered natriuretic peptide antagonizes the pressor response and elevation of plasma vasopressin level caused by intracerebroventricular injection of endothelin-1. And lastly, ANP inhibits production and release of endothelin-1 from endothelial cells [118]. This antagonism between ANP and endothelins is reminiscent of that between ANP and antagiotensin II, suggesting that ANP may act as a negative feedback regulator to oppose the overactivity of the pressor system composed of angiotensin II and endothelin-1.

\section{Stimulation of Aldosterone and Catecholamine Secretion from Adrenals}

Autoradiographic and binding studies demonstrated specific binding sites for ${ }^{125}$ I-endothelin-1 in both adrenal cortex and medulla [7]. Adrenal medulla showed a higher density of binding of ${ }^{125}$ I-endothelin-1 compared with cortex [7, 119]. Northern blot analysis revealed that adrenals express mRNAs for both $\mathrm{ET}_{\mathrm{A}}$ and $\mathrm{ET}_{\mathrm{B}}$ endothelin receptors [15, 29, 30]. Adrenal tissues (cortex plus medulla) were also reported to contain endothelin-
1 and to a lesser extent, endothelin-3, and Northern blot analysis detected mRNAs for both peptides [120-122]. A more detailed study demonstrated that adrenal cortical tissues express mRNAs for both receptor subtypes and peptides [122].

Systemic infusion of endothelin-1 induces elevation of plasma levels of aldosterone [8, 18]. Endothelin-1 infusion causes a rise in plasma renin activity, which is probably secondary to vasoconstriction of the renal vessels proximal to the juxtaglomerular cells because endothelins are shown to have a direct inhibitory effect on renin release from juxtaglomerular cells [123, 124]. In addition to this effect, endothelins were demonstrated to directly act on adrenal glomerulosa cells causing stimulation of aldosterone secretion [125-128]. The in vitro stimulatory effects of endothelins on aldosterone secretion is relatively weak compared to that of angiotensin II, a major regulatory factor for aldosterone secretion [125-128]. The endothelin receptor subtype which mediates the secretory effect of endothelins is not yet conclusively determined [129, 130]. Interestingly, aldosterone-secreting adenoma expresses endothelin receptors but do not respond to endothelin- 1 with aldosterone secretion just as it is refractory to angiotensin II which acts as a $\mathrm{Ca}^{2+}$-mobilizing peptide like endothelin-1 [128]. Endothelin peptides cause activation of phospholipase $\mathrm{C}$ and a biphasic increase in $\left[\mathrm{Ca}^{2+}\right] \mathrm{i}$ in glomerulosa cells [127]. The aldosterone-secretory response by endothelin- 1 is inhibited by either removal of extracellular $\mathrm{Ca}^{2+}$ or addition of a dihydropyridine $\mathrm{Ca}^{2+}$ channel antagonist, as in other cell types [125]. The target of a dihydropyridine $\mathrm{Ca}^{2+}$ channel antagonist is probably a voltage-dependent $\mathrm{Ca}^{2+}$ channels of $\mathrm{T}$ type in glomerulosa cells [131], since this type of $\mathrm{Ca}^{2+}$ channels are considered to be a major $\mathrm{Ca}^{2+}$ channel through which $\mathrm{Ca}^{2+}$ influx occurs in response to angiotensin II stimulation.

Systemic administration of endothelin-1 causes elevation of plasma levels of adrenaline and noradrenaline [8, 18]. Cultured bovine adrenal chromaffin cells were demonstrated to possess specific binding sites for endothelins with similar affinities for both endothelin-1 and endothelin-3, presumably $\mathrm{ET}_{\mathrm{B}}$ receptors [132]. Addition of endothelin-1 to cultured adrenal cells induces release of adrenaline and noradrenaline [133, 134]. However, endothelin-1 is a very weak secre- 
tagogue and does not alter secretion induced by high $\mathrm{KCl}$ or nicotine. Adrenal chromaffin cells express abundant voltage-dependent $\mathrm{Ca}^{2+}$ channels of L-type. However, the endothelin-1-induced catecholamine secretion is only partially inhibited by a dihydropyridine $\mathrm{Ca}^{2+}$ channel antagonist, which is distinct from high $\mathrm{KCl}$ and nicotineinduced responses [133]. In these studies endothelin-1 failed to stimulate phospholipase C [133, 134].

\section{Summary}

Endothelin family peptides are now known to exert diverse biological effects on a wide variety of tissues and cell types through at least two subtypes of receptors. In vascular systems, both $\mathrm{ET}_{\mathrm{A}}$ and $\mathrm{ET}_{\mathrm{B}}$ endothelin receptors present in vascular smooth muscle mediate the vasoconstrictor and mitogenic activities of the peptides, while $\mathrm{ET}_{\mathrm{B}}$ receptors in the endothelium mediate the vasodila- tor and antiplatelet activities. Endothelins also affect hormone secretion from a variety of endocrine organs including anterior and posterior pituitary, atria and adrenals. Endothelins activate the $\mathrm{Ca}^{2+}$-messenger system which involves both calmodullin and protein kinase $\mathrm{C}$ to exert their biological activities in almost all cell types examined, and appear to work in a paracrine and autocrine fashion. However, physiological and pathophysiological roles of endothelins are still incompletely understood and further studies are clearly required for elucidation of biological significance of this peptide family.

\section{Acknowledgments}

I thank Mrs. N. Miyamoto for expert secretarial assistance. This work was supported by grants from the Ministry of Education, Science and Culture of Japan and Tsumura Foundation for Cardiovascular Research.

\section{References}

1. Yanagisawa M, Kurihara H, Kimura S, Tomobe Y, Kobayashi M, Mitsui Y, Yazaki Y, Goto K, Masaki T (1988) A novel potent vasoconstrictor peptide produced by vascular endothelial cells. Nature 332: 411-415.

2. Yanagisawa M, Masaki T (1989) Endothelin, a novel endothelium-derived peptide. Pharmacological activities, regulation and possible roles in cardiovascular control. Biochem Pharmacol 38: 1877-1883.

3. Takuwa Y, Yanagisawa M, Takuwa N, Masaki T (1989) Endothelin, its diverse biological activities and mechanisms of action. Prog Growth Factor Res 1: 195-206.

4. Masaki T, Kimura S, Yanagisawa M, Goto K (1991) Molecular and cellular mechanism of endothelin regulation, implications for vascular function. Circ Res 84: 1457-1468.

5. de Nucci G, Thomas R, D'Orleans-Juste P, Antunes E, Walder C, Warner T, Vane JR (1988) Presson effects of circulating endothelin are limited by its removal in the pulmonary circulation and by the release of prostacyclin and endothelium-derived relaxing factor. Proc Natl Acad Sci USA 85: 9797-9800.

6. Warner TD, de Nucci G, Vane JR (1989) Rat endothelin is a vasodilator in the isolated perfused mesentery of the rat. Eur $J$ Pharmacol 159:
$325-326$.

7. Koseki C, Imai M, Hirata Y, Yanagisawa M, Masaki T (1989) Autoradiographic distribution in rat tissues of binding sites for endothelin: a neuropeptide? Am J Physiol 256: R858-R866.

8. Goetz KL, Wang BC, Madwed JB, Zhu JL, Leadley JJr (1988) Cardiovascular, renal, and endocrine responses to intravenous endothelin in conscious dogs. Am J Physiol 255: R1064-R1068.

9. Goetz K, Wang BC, Leadley JJr, Zhu JL, Madwed JB, Bie P (1989) Endothelin and sarafotoxin produce dissimilar effects of renal blood flow, but both block the antidiuretic effects of vasopressin. Proc Suc Exp Biol Med 191: 425-427.

10. Tomita K, Nonoguchi H, Marumo F (1990) Effects of endothelin on peptide-dependent cyclic adenosine monophosphate accumulation along the nephron segments of the rat. J Clin Invest 85 : 2014-2018.

11. Yoshizawa T, Kimura S, Kanazawa I, Yanagisawa M, Goto K, Masaki T (1989) Endothelin localizes in the dorsal horn and acts on the spinal neurons: possible involvement of dihydropyridine sensitive calcium channels and substance $P$ release. Neurosci Lett 102: 179-184.

12. Inoue $A$, Yanagisawa M, Kimura S, Kasuya $\mathrm{Y}$, Miyauchi T, Goto K, Masaki T (1989) The human endothelin family: three structurally and phar- 
macologically distinct isopeptides predicated by three separate genes. Proc Natl Acad Sci USA 86: 2863-2867.

13. Watanabe $\mathrm{H}$, Miyazaki H, Kondoh M, Masuda $\mathrm{Y}$, Kimura S, Yanagisawa M, Masaki T, Murakami K (1989) Two distinct types of endothelin receptors are present on chick cardiac membranes. Biochem Biophys Res Commun 161: 1252-1259.

14. Arai H, Hori S, Aramori I, Ohkubo H, Nakanishi $S$ (1990) Cloning and expression of a cDNA encoding an endothelin receptor. Nature 348: 730-732.

15. Sakurai T, Yanagisawa M, Takuwa Y, Miyazaki H, Kimura S, Goto K, Masaki T (1990) Cloning of cDNA encoding a nonisopeptide-selective subtype of the endothelin receptor. Nature 348: $732-735$.

16. Saeki T, Ihara M, Fukuroda T, Yamagiwa M, Yano M (1991) [Ala ${ }^{1,3,11,15}$ ]endothelin-1 analogs with $\mathrm{ET}_{\mathrm{B}}$ agonistic activity. Biochem Biophys Res Commun 179: 286-292.

17. Ihara M, Fukuroda T, Saeki T, Nishikibe M, Kujiri K, Suda H, Yano M (1991) An endothelin receptor $\left(\mathrm{ET}_{\mathrm{A}}\right)$ antagonist isolated from streptomyces misakiensis. Biochem Biophys Res Commun 178: 132-137.

18. Miller WL, Redfield MM, Burnett JCJr (1989) Integrated cardiac, renal, and endocrine actions of endothelin. J Clin Invest 83: 317-320.

19. Kurihara T, Akimoto M, Kurokawa K, Ishiguro H, Niimi A, Maeda A, Sigemoto M, Yamashita K, Yokoyama I, Hirayama Y, Ihara M, Yano M (1992) Relationship between endothelin and thromboxane $\mathrm{A}_{2}$ in rat liver microcirculation. Life Sci 51: 281-285.

20. Shirahase H, Usui H, Shimaji H, Kurahashi K, Fujiwara M (1991) Endothelium-independent and-dependent contractions induced by endothelin-1 in canine basilar arteries. Life Sci 49: 273-281.

21. Taddei S, Vanhoutte PM (1993) Role of endothelium in endothelin-evoked contractions in the rat aorta. Hypertension 21: 9-15.

22. Ihara K, Noguchi K, Saeki T, Fukuroda T, Tsuchida S, Kimura S, Fukami T, Ishikawa K, Nishikibe M, Yano M (1991) Biological profiles of highly potent novel endothelin antagonists selective for the $\mathrm{ET}_{\mathrm{A}}$ receptor. Life Sci 50: 247-255.

23. Bazil MK, Lappe RW, Webb RL (1992) Pharmacologic characterization of an Endothelin ${ }_{\mathrm{A}}\left(\mathrm{ET}_{\mathrm{A}}\right)$ receptor antagonist in conscious rats. J Cardiovasc Pharmacol 20 : 940-948.

24. Douglas SA, Elliott JD, Ohlstein EH (1992) Regional vasodilation to endothelin- 1 is mediated by a non-ET $\mathrm{A}_{\mathrm{A}}$ receptor subtype in the anaesthetized rat: effect of $\mathrm{BQ}-123$ on systemic haemodynamic responses. Eur J Pharmacol 221: 315-324.

25. Bigand M, Pelton JT (1992) Discrimination be- tween $\mathrm{ET}_{\mathrm{A}}$-and $\mathrm{ET}_{\mathrm{B}}$-receptor-mediated effects of endothelin-1 and [Ala $\left.{ }^{1,3,11,15}\right]$ endothelin-1 by $\mathrm{BQ}-123$ in the anaesthetized rat. Br J Pharmacol 107: 912-918.

26. Pollock D, Opgenorth TJ (1993) Evidence for endothelin-induced renal vasoconstriction independent of $\mathrm{ET}_{\mathrm{A}}$ receptor activation. Am J Physiol 264: R222-226.

27. Fukuroda $\mathrm{T}$, Nishikibe $\mathrm{M}$, Ohta $\mathrm{Y}$, Ihara M, Yano M, Ishikawa K, Fukami T, Ikemoto F (1992) Analysis of responses to endothelins in isolated porcine blood vessels by using a novel endothelin antagonist, BQ-153. Life Sci 50: PL107-PL112.

28. Sumner MJ, Cannon TR, Mundin JW, White DG, Watts IS (1992) Endothelin $\mathrm{ET}_{\mathrm{A}}$ and $\mathrm{ET}_{\mathrm{B}}$ receptors mediate vascular smooth muscle contraction. Br J Pharmacol 107: 858-860.

29. Ogawa $Y$, Nakao K, Arai H, Nakagawa O, Hosoda K, Suda S, Nakanishi S, Imura H (1991) Molecular cloning of a non-isopeptide-selective human endothelin receptor. Biochem Biophys Res Commun 178: 248-255.

30. Hosoda K, Nakao K, Arai H, Suda S, Ogawa Y, Mukoyama K, Shirakami G, Saito Y, Nakanishi S, Imura H (1991) Cloning and expression of human endothelin-1 receptor cDNA. FEBS lett 287: 23-26.

31. Moreland S, McMullen DM, Delaney Cl, Lee VG, Hunt JT (1992) Venous smooth muscle contains vasoconstrictor $\mathrm{ET}_{\mathrm{B}}$-like receptors. Biochem Biophys Res Commun 184: 100-106.

32. Emori T, Hirata Y, Marumo F (1990) Specific receptors for endothelin-3 in cultured bovine endothelial cells and its cellular mechanism of action. FEBS lett 263: 261-264.

33. Woodcock EA, Land S (1991) Endothelin receptors in rat renal papilla with a high affinity for endothelin-3. Eur J Pharmacol 208: 255-260.

34. Sakamoto A, Yanagisawa M, Sakurai T, Takuwa Y, Yanagisawa M, Masaki T (1991) Cloning and functional expression of human cDNA for the $\mathrm{ET}_{\mathrm{B}}$ endothelin receptors. Biochem Biophys Res Commun 178: 656-663.

35. Ohno A, Kato S, Naruse M, Hosaka M, Naruse K, Demura H, Sugino N (1990) Renal and systemic effects of endothelin and anti-endothelin antibody in spontaneously hypertensive rats. J Hypertense 8 (suppl. 3): S11, ID. 20.

36. Saito Y, Nakao K, Mukoyama M, Imura H (1990) Increased plasma endothelin level in patients with essential hypertension. N Engl J Med 322: 205.

37. Shichiri M, Hirata Y, Ando K, Emori T, Ohta K, Kimoto S, Ogura M, Inoue A, Mrumo F (1990) Plasma endothelin levels in hypertension and chronic renal failure. Hypertension 15: 493-496.

38. Yokokawa K, Tahara H, Kohno M, Murakawa K, Yasunari K, Nakafawa K, Hamada T, Otani S, Yanagisawa M, Takeda T (1991) Hypertension 
associated with endothelin-secreting malignant hemangioendothelioma. Ann Intern Med 114: 213-215.

39. Yoshimoto S, Ishizaki I, Mori A, Sasaki T, Takakura K, Murota S (1990) The role of cerebralmicrovessel endothelium in regulation of cerebral blood flow through production of endothelin-1. J Vasc Med Biol 2: 179.

40. Kurihara Y, Kurihara H, Suzuki H, Kaemura K, Kodama T, Nagai R, Yazaki Y (1993) The generation of endothelin-1-deficiency mice using the homologous recombination. Japanese Circulation J 57 (Suppl): 94 (abstract) (In Japanese).

41. Yamamoto T, Kimura T, Ota K, Shoji M, Inoue M, Sato K, Ohta M, Yoshinaga K (1992) Central effects of endothelin-1 on vasopressin release, blood pressure and renal solute excretion. $A m J$ Physiol 262: E856-E862.

42. Ouchi Y, Kim S, Souza AC, Iijima S, Hattori A, Orimo H, Yoshizumi M, Kurihara H, Yazaki Y (1989) Central effect of endothelin on blood pressure in conscious rats. Am J Physiol 256: H1747-H1751.

43. Makino S, Hashimoto $\mathrm{K}$, Hirasawa R, Hattori $\mathrm{T}$, Kageyama J, Ota Z (1990) Central interaction between endothelin and brain natriuretic peptide on pressor and hormonal responses. Brain Res 534: 117-121.

44. Kuwaki T, Koshiya N, Takahashi H, Terui N, Kumada M (1990) Modulatory effects of rat endothelin on central cardiovascular control in rats. Jap J Physiol 40: 91-116.

45. Kuwaski T, Koshiya N, Cao WH, Terui N, Kumada N (1990) Modulatory effects of endothelin-1 on sentral cardiovascular control in rats. Jap J Physiol 40: 827-841.

46. Kuwaki T, Cao WH, Unekawa M, Terui N, Kumada M (1991) Endothelinsensitive areas in the ventral surface of the rat medulla. J Auton Nerv Syst 36: 149-158.

47. Asano T, Ikegaki I, Suzuki Y, Satoh S, Shibuya M (1989) Endothelin and the production of cerebral vasospasm in dogs. Biochem Biophys Res Commun 159: 1345-1351.

48. Mima T, Yanagisawa M, Shigeno T, Saito A, Goto K, Takakura K, Masaki T (1989) Endothelin acts in feline and canine cerebral arteries from the adventitial side. Storke 20: 1553-1556.

49. Shigeno T, Mima T, Takakura K, Yanagisawa M, Saito A, Goto K, Masaki T (1991) Prevention of cerebral vasospasm by actinomycin D. J Neurosurg 74: 940-943.

50. Fujimori A, Yanagisawa M, Saito A, Goto K, Masaki T, Mima T, Takakura K, Shigeno T (1990) Endothelin in plasma and cerebrospinal fluid of patients with subarachnoid haemorrhage. Lancet 336: 633.

51. Ide K, Ito T, Sasaki T, Kirino T (1993) Effects of
$\mathrm{ET}_{\mathrm{A}}$ receptor antagonist on normal and spastic canine basilar arteries. Can J Neurol Sci 20 (suppl. 1): S15 (abstract).

52. Matsui T, Takuwa Y, Johshita H, Yamashita K, Asano T (1991) Possible role of protein kinase C-dependent smooth muscle contraction in the pathogenesis of chronic cerebral vasospasm. J Cereb Blood Flow Metal 11: 143-149.

53. Ross R (1993) The pathogenesis of atherosclerosis: a perspective for the 1990s. Nature 362: 801-810.

54. Lerman A, Edwards BS, Hallett JW, Heublein DM, Sandberg SM, Burnett JCJr (1991) Circulating and tissue endothelin immunoreactivity in advanced atherosclerosis. $N$ Engl $J$ Med 325: 997-1001.

55. Komuro I, Kurihara H, Sugiyama T, Takaku F, Yazaki Y (1988) Endothelin stimulates c-fos and c-myc expression and proliferation of vascular smooth muscle cells. FEBS lett 238: 249-252.

56. Bobik A, Grooms A, Millar JA, Mitchell A, Grinpukel S (1990) Growth factor activity of endothelin on vascular smooth muscle. Am J Physiol 258: C408-C415.

57. Eguchi A, Imai T, Emori T, Sugano K, Ohta K, Tsujino M, Iwashina M, Hirata Y, Marumo F (1993) Expression of $\mathrm{ET}_{\mathrm{B}}$ endothelin receptor in long term cultures of vascular smooth muscle cells. Folia Endocrinol Japon 69: 406 (abstract) (In Japanese).

58. Resink TJ, Scott-Burden T, Buhler FR (1988) Endothelin stimulates phospholipase $\mathrm{C}$ in cultured vascular smooth muscle cells. Biochem Biophys Res Commun 157: 1360-1368.

59. Kasuya Y, Takuwa Y, Yanagisawa M, Kimura S, Goto K, Masaki T (1989) Endothelin-1 induces vasoconstriction through two functionally distinct pathways in porcine coronary artery: Contribution of phosphoinositide turnover. Biochem Biophys Res Commun 161: 1049-1055.

60. Goto K, Kasuya Y, Matsuki N, Takuwa Y, Kurihara H, Ishikawa T, Kimura S, Yanagisawa M, Masaki T (1989) Endothelin avtivates the dihydropyridine-sensitive, voltage-dependent Ca channel in vascular smooth muscle. Proc Natl Acad Sci USA 86: 3915-3918.

61. Berridge MJ (1993) Inositol trisphosphate and calcium signalling. Nature 361: 315-325.

62. Nishizuka Y (1984) The role of protein kinase C in cell surface signal transduction and tumor promotion. Nature 308: 693-698.

63. MacNulty EE, Plevin R, Wakelam MJD (1990) Stimulation of the hydrolysis of phosphatidylinositol 4, 5-bisphosphate and phosphatidylcholine by endothelin, a complete mitogen for Rat-1 fibroblasts. Biochem J 272: 761-766.

64. Takuwa Y, Kasuya Y, Takuwa N, Kudo M, Yanagisawa M, Goto K, Masaki T, Yamashita K 
(1990) Endothelin receptor is coupled to phospholipase $\mathrm{C}$ via a pertussis toxin-insensitive guanine-nucleotide binding regulatory protein in vascular smooth muscle cells. J Clin Invest 85: 653-658.

65. Brinbaumer L (1992) Receptor-to-effector signalling through $\mathrm{G}$ protein: roles for $\beta \gamma$ dimers as well as $\alpha$ subunits. Cell 71: 1069-1072.

66. Aramori I, Nakanishi S (1992) Coupling of two endothelin receptor subtypes of differing signal transduction in transfected chinese hamster ovary cells. I Biol Chem 267: 12468-12474.

67. Ohlstein EH, Horohonich S, Hay DWP (1989) Cellular mechanisms of endothelin in rabbit aorta. J Pharmacol Exp Ther 250: 548-555.

68. Kasuya Y, Ishikawa T, Yanagisawa M, Kimura S, Goto K, Masaki T (1989) Mechanism of contraction to endothelin in the isolated porcine coronary artery. Am J Physiol 257: H1828-H1835.

69. Silberberg SD, Poder TC, Lacerda AE (1989) Endothelin increases single-channel calcium currents in coronary arterial smooth muscle. Cells 247: 68-72.

70. Godfraind T (1992) Selective Ca channels modulators in smooth muscle. Jpn J Pharmacol 58 (Suppl. II): 243p-250p.

71. Godfraind T, Morel N, Wibo M (1988) Tissue specificity of dihydropyridine-type calcium antagonists in human isolated tissues. Trend Pharmacol Sci 9: 37-39.

72. Nakao K, Inoue $\mathrm{Y}$, Oike M, Kitamura K, Kuriyama H (1990) Mechanisms of endothelininduced augmentation of the electrical and mechanical activity in rat portal vein. Pflügers Arch 415: 526-532.

73. Klöckner U, Isenberg G (1991) Endothelin depolarizes myocytes from porcine cornary and human mesenteric arteries through a $\mathrm{Ca}^{2+}$. activated chloride current. Pflügers Arch 418: $168-175$.

74. Adam LP, Millo J, Brengle B, Hathaway DL (1990) Myosin light chain and caldesmon phosphorylation in arterial muscle stimulated with endothelin-1. J Mol Cell Caediol 22: 1017-1023.

75. Abe Y, Kasuya Y, Kudo M, Yamashita K, Goto K, Masaki T, Takuwa Y (1991) Endothelin-1induced phosphorylation of the 20-kDa myosin light chain and caldesmon in porcine coronary artery smooth muscle. Jpn J Pharmacol 57: $431-435$.

76. Nishimura J, Khakik RA, Drenth JP, VanBreemen C (1990) Evidence for increased myofilament $\mathrm{Ca}^{2+}$ sensitivity in norepinephrine-activated vascular smooth muscle. Am J Physiol 259: $\mathrm{H} 2-\mathrm{H} 8$.

77. Kitazawa T, Gaylinn BD, Denney GH, Somlyo AP (1991) G-protein-mediated $\mathrm{Ca}^{2+}$ sensitization of smooth muscle contraction through myosin light chain phosphorylation. $J$ Biol Chem 266: 1708-1715.

78. Hirata K, Kikuchi A, Kuroda S, Kaibuchi K, Matsuura Y, Seki H, Saida K, Takai Y (1992) Involvement of rho p21 in the GTP-enhanced calcium ion sensitivity of smooth muscle contraction. J Biol Chem 267: 8719-8722.

79. Rasmussen H, Takuwa Y, Park S (1987) Protein kinase $\mathrm{C}$ in the regulation of smooth muscle contraction. FASEB J 1: 177-185.

80. Haller H, Smallwood JI, Rasmussen H (1990) Protein kinase $\mathrm{C}$ translocation in intact vascular smooth muscle strip. Biochem J 270: 375-381.

81. Takuwa Y, Kelley G, Takuwa N, Rasmussen H (1988) Protein phosphorylation changes in bovine carotid artery smooth muscle during contraction and relaxation. Mol Cell Endocrinol 60: 71-86.

82. Takayanagi R, Kitazawa K, Takasaki C, Ohnaka K, Aimoto S, Tasaka K, Ohashi M, Nawata H (1991) Presence of non-selective type of endothelin receptor on vascular endothelium and its linkage to vasodilation. FEBS lett 282: 103-106.

83. Sudjarwo SA, Hori M, Karaki H (1992) Effect of endothelin-3 on cytosolic calcium level in vascular endothelium and on smooth muscle contraction. Eur J Pharmacol 229: 137-142.

84. Förstermann U, Pollock JS, Nakane M (1993) Nitric oxide synthases in the cardiovascular system. Trends Cardiovasc Med 3: 104-110.

85. Murad F (1986) Cyclic guanosine monophosphate as a mediator of vasodilation. J Clin Invest 78: $1-5$.

86. Lin LL, Wartman M, Lin AY, Knopf JL, Seth A, Davis RJ (1993) cPLA $_{2}$ is phosphorylated and activated by MAP kinase. Cell 72: 269-278.

87. Takuwa N, Takuwa Y, Yanagisawa M, Yamashita K, Masaki T (1989) A novel vasoactive peptide endothelin stimulates mitogenesis through inositol lipid turnover in Swiss 3T3 fibroblasts. $J$ Biol Chem 264: 7856-7861.

88. Badr K, Murray JJ, Breyer MD, Takahashi K, Inagami T, Harris RC (1989) Mesangial cell, glomerular and renal vascular responses to endothelin in the rat kidney. $J$ Clin Invest 83: 336-342.

89. Takuwa Y, Ohue Y, Takuwa N, Yamashita K (1989) Endothelin-1 activates phospholipase C and mobilizes $\mathrm{Ca}^{2+}$ from extra-and intracellular pools in osteoblastic cells. Am $J$ Physiol 257: E797-E803.

90. Takuwa Y, Masaki T, Yamashita K (1990) The effects of the endothelin family peptides on cultured osteoblastic cells from rat calvarie. Biochem Biophys Res Commun 170: 998-1005.

91. Takuwa N, Takuwa Y, Bollag WE, Rasmussen H (1987) The effects of bombesin on polyphos- 
phoinositide and calcium metabolism in Swiss 3T3 Cells. J Biol Chem 262: 182-188.

92. Takuwa N, Zhou W, Kumada M, Takuwa Y (1992) Activators of protein kinase $\mathrm{C}$ induce p34 ${ }^{\text {cdc2 }}$ histone $\mathrm{Hl}$ kinase stimulation in Swiss 3T3 fibroblasts. Biochem Biophys Res Commun 188: 1084-1089.

93. Takuwa N, Iwamoto A, Kumada M, Yamashita K, takuwa Y (1991) Role of $\mathrm{Ca}^{2+}$ influx in bombesininduced mitogenesis in Swiss 3T3 fibroblasts. $J$ Biol Chem 266: 1403-1409.

94. Zhou W, Takuwa N, Kumada M, Takuwa Y (1993) Protein kinase C-mediated bidirectional regulation of DNA synthesis, RB protein phosphorylation and cyclin-dependent kinases in human vascular endothelial cells. J Biol Chem (In Press).

95. Takuwa N, Zhou W, Kumada M, Takuwa Y (1993) $\mathrm{Ca}^{2+}$-dependent stimulation of $\mathrm{RB}$ gene product phosphorylation and $\mathrm{p} 34^{\mathrm{cdc} 2}$ kinase activation in serum-stimulated human fibroblasts. J Biol Chem 268: 138-145.

96. Brown KD, Littlewood CJ (1989) Endothelin stimulates DNA synthesis in Swiss 3T3 cells. Biochem J 263: 977-980.

97. Johes CR, Hiley CR, Pelton JT, Mohr M (1989) Autoradiographic visualization of binding sites for ${ }^{125} \mathrm{I}$ endothelin in rat and human brain. Neurosci Lett 97: 276-279.

98. Wall KM, Ferguson AU (1992) Endothelin acts at the subfornical organ to influence the activity of putative vasopressin and oxytocin-secreting neurons. Brain Res 586: 111-116.

99. Shichiri M, Hirata Y, Kanno K, Ohta K, Emori T, Marumo F (1989) Effect of endothelin-1 on release of arginine-vasopressin from perfused rat hypothalamus. Biochem Biophys Res Commun 163: 1332-1337.

100. Yamashita H, Yamamoto S, Inenaga K (1991) Endothelin-3 directly affects neurons in the anteroventral third ventricle region and supraoptic nucleus of the rat hypothalamus in vitro. $J$ Cardiovasc Pharmacol 17: 5200-5202.

101. Calvo JJ, Gonzalez R, De Carvalho F, Takahashi K, Kanse SM, Hart GR, Ghatei MA, Bloom SR (1990) Release of substance P from rat hypothalamus and pituitary by endothelin. Endocrinol 126 : 2288-2295.

102. Krsmanovic LZ, Stojilkovic SS, Balla T, AlDamluji S, Weiner RI, Catt KJ (1991) Receptors and neurosecretory actions of endothelin in hypothalamic neurons. Proc Natl Acad Sci USA 88: 11124-11128.

103. Yoshizawa T, Shinmi O, Giaid A, Yanagisawa M, Gibson SJ, Kimura S, Uchiyama Y, Polak JM, Masaki T, Kanazawa I (1990) Endothelin: A novel peptide in the posterior pituitary system. Science
247: 462-464.

104. Samson WK, Skala KD, Alexander B, Huang FLS (1991) Possible neuroendocrine action of endothelin-3. Endocrinol 128: 1465-1473.

105. Samson WK, Skala KD, Alexander B, Huang FLS (1990) Pituitary site of action of endothelin: selective inhibition of prolactin release in vitro. Biochem Biophys Res Commun 169: 737-743.

106. Samson WK (1992) The endothelin-A receptor subtype transduces the effects of the endothelins in the anterior pituitary gland. Biochem Biophys Res Commun 187: 590-595.

107. Kanyicska B, Burris T, Freeman ME (1991) Endothelin-3 inhibits prolactin and stimulates LH, FSH and TSH secretion from pituitary cell culture. Biochem Biophys Res Commun 174: 338-343.

108. Dymshitz J, Laudon M, Ben-Jonathan M (1992) Endothelin-induced biphasic response to lactotrophs cultured under different condition. Neuroendocrinol 55: 724-729.

109. Domae M, Yamada K, Hanabusa Y, Furukawa T (1992) Inhibitory effects of endothelin-1 and endothelin-3 on prolactin release: possible involvement of endogenous endothelin isopeptides in the rat anterior pitutary. Life Sci 50: 715-722.

110. Stojilkovic SS, Balla T, Fukuda S, Cesnjaj M, Merelli F, Krsmanovic LZ, Catt KJ (1992) Endothelin $\mathrm{ET}_{\mathrm{A}}$ receptors mediate the signaling and secretory actions of endothelins in pituitary gonadotrophs. Endocrinol 130: 465-474.

111. Stojilkovic SS, Merelli F, Iida T, Krsmanovic LZ, Catt KJ (1990) Endothelin stimulation of cytosolic calcium and gonadotropin secretion in anterior pituitary cells. Science 248: 1663-1666.

112. Burris TP, Kanyicska B, Freeman ME (1991) Inhibition of prolactin secretion by endothelin-3 is pertussis toxin-sensitive. Eur J Pharmacol 198: 223-225.

113. Fukuda Y, Hirata Y, Yoshimi H, Kojima T, Kobayashi Y, Yanagisawa M, Masaki T (1988) Endothelin is a potent secretagogue for atrial natriuretic peptide in cultured rat atrial myocytes. Biochem Biophys Res Commun 155: 167-172.

114. Winquist RJ, Scott AL, Vlasuk GP (1989) Enhanced release of atrial natriuretic factor by endothelin in atria from hypertensive rats. Hypertension 14: 111-114.

115. Uusimaa PA, Hassinen IE, Vuolteenaho O, Ruskoaho H (1992) Endothelin-induced atrial natriuretic peptide release from cultured neonatal cardiac myocytes: the role of extracellular calcium and protein kinase C. Endocrinol 130: 2455-2464.

116. Gardner DG, Newman ED, Nakamura KK, Nguyen KP (1991) Endothelin increases the synthesis and secretion of atrial natriuretic peptide in neonatal rat cardiocytes. Am J Physiol 261: 
E177-E182.

117. Schiebinger RJ, Greening KM (1992) Intraction between stretch and hormonally stimulated atrial natriuretic peptide secretion. Am J Physiol 262: $\mathrm{H} 78-\mathrm{H} 83$.

118. Hu RM, Levin ER, Pedram A, Frank HJ (1992) Atrial natriuretic peptide inhibits the production and secretion of endothelin from cultured endothelial cells. Mediation through the $\mathrm{C}$ receptor. J Biol Chem 267: 17384-17389.

119. Kohzuki M, Johnston CI, Chai SY, Casley DJ, Rogerson F, Mendelsohn FA (1989) Endothelin receptors in rat adrenal gland visualized by quantitative autoradiography. Clin Exp Pharmacol Physiol 16: 239-242.

120. Sakurai T, Yanagisawa M, Inoue A, Ryan US, Kimura S, Mitsui Y, Goto K, Masaki T (1991) cDNA cloning, sequence analysis and tissue distribution of rat preproendothelin-1 mRNA. Biochem Biophys Res Commun 175: 44-47.

121. Shiba R, Sakurai T, Yamada G, Morimoto H, Saito A, Masaki T, Goto K (1992) Cloning and expression of rat preproendothelin-3 cDNA. Biochem Biophys Res Commun 186: 588-594.

122. Imai T, Hirata Y, Eguchi S, Kanno K, Ohta K, Emori T, Sakamoto A, Yanagisawa M, Masaki T, Marumo F (1992) Concomitant expression of receptor subtype and isopeptide of endothelin by human adrenal gland. Biochem Biophys Res Commun 182: 1115-1121.

123. Rakugi M, Kanamura M, Saito H, Higaki J, Ogihara T (1988) Endothelin inhibits renin release from isolated rat glomeruli. Biochem Biophys Res Commun 155: 1244-1247.

124. Takagi M, Matsuoka H, Atarashi K, Yagi S (1988) Endothelin; a new inhibitor of renin release. Biochem Biophys Res Commun 157: 1164-1168.

125. Morishita R, Higaki J, Ogihara T (1989) Endothelin stimulates aldosterone biosynthesis by dispersed rabbit adreno-capusular cells. Biochem Biophys Res Commun 160: 628-632.

126. Cozza EN, Gomez-Sanchez E, Foecking MF, Chiou S (1989) Endothelin binding to cultured calf adrenal zona glomerulosa cells and stimulation of aldosterone secretion. J Clin Invest 84: 1032-1035.

127. Woodcock EA, Little PJ, Tanner JK (1990) Inositol phosphate release and steroidogenesis in rat adrenal glomerulosa cells. Biochem J 271: 791-796.

128. Zeng Z, Naruse M, Guan B, Naruse K, Sun M, Zang M, Demura H, Shi Y (1992) Endothelin stimulates aldosterone secretion in vitro from normal adrenocortical tissue, but not adenoma tissues in primary aldosteronism. J Clin Endocrinol Metab 74: 874-878.

129. Gomez-Sanchez C, Cozza EN, Foecking MF, Chiou S, Ferris MW (1990) Endothelin receptor subtypes and stimulation of aldosterone secretion. Hypertension 15: 744-747.

130. Hinson JP, Vinson GP, Kapas S, Teja R (1991) The role of endothelin in the control of adrenocortical function: stimulation of endothelin release by ACTH and the effects of endothelin-1 and endothelin-3 on steroidogenesis in rat and human adrenocortical cells. J Endocrinol 128: 275-280.

131. Cohen CJ, MacCarthy RT, Barret PQ, Rasmussen $H$ (1988) Ca channels in adrenal glomerulosa cells: $\mathrm{K}^{+}$and angiotensin II increase T-type Ca channel current. Proc Natl Acad Sci USA 85: 2412-2416.

132. Wilkes LC, Boarder MR (1991) Characterization of the endothelin binding site on bovine adrenomedullary chromaffin cells: comparison with vascular smooth muscle cells. Evidence for receptor heterogeneity. J Pharmacol Exp Ther 256: 628-633.

133. Boarder MR, Marriott DB (1991) Endothelin-1 stimulation of noradrenaline and adrenaline release from adrenal chromaffin cells. Biochem Pharmacol 41: 521-526.

134. Rasmussen K, Printz MP (1989) Depolarization potentiates endothelin-induced effects on cytosolic calcium in bovine adrenal chromaffin cells. Biochem Biophys Res Commun 165: 306-311.

135. Schnermann J, Lorenz JN, Briggs JP, Keiser JA (1992) Induction of water diuresis by endothelin in rats. Am $J$ Physiol 263: F516-F526.

136. Kodama M, Kanaide H, Abe S, Hirano L, Kai H, Nakamura M (1989) Endothelin-induced Caindependent contraction of the porcine coronary artery. Biochem Biophys Res Commun 160: 1302-1308.

137. Matsumoto $H$, Suzuki $N$, Onda $H$, Fujino $M$ (1989) Abundance of endothelin-3 in rat intestine, pituitary gland and brain. Biochem Biophys Res Commun 164: 74-80.

138. Shichiri M, Hirata Y, Nakajima T, Ando K, Imai T, Yanagisawa M, Masaki T, Marumo F (1991) Endothelin-1 is an autocrine/paracrine growth factor for human cancer cell lines. J Clin Invest 87: 1867-1871. 